\title{
Democratizando a ciência? Júris de cidadãos e outras metodologias deliberativas *
}

\author{
Democratizing science? Citizen juries and other \\ deliberative methods
}

\author{
Tom Shakespeare \\ Diretor de extensão do \\ Policy, Ethics and Life Sciences \\ Research Institute \\ (www.peals.ncl.ac.uk). ${ }^{* *}$ \\ Times Square, Scotswood Road, \\ Newcastle NE1 4EP - UK \\ t.w.shakespeare@ncl.ac.uk
}

$\mathrm{N}$

o Reino Unido, há um movimento recente de crítica à forma como a ciência tem se tornado distante da sociedade. A ciência e os cientistas estão longe do contato e das preocupações das pessoas. Critica-se, ainda, a distinção que se costuma fazer entre ciência e sociedade ou entre ciência e suas aplicações. Os cientistas são, obviamente, homens públicos; a ciência é financiada pela sociedade e pelo governo. Portanto, a ciência deve ser acessível ao público. A sociedade deve traçar os limites da aplicação científica e decidir como esta deve se tornar parte da vida cotidiana. A ciência em si, como uma busca e um processo, deve ser livre, mas suas aplicações afetam a todos. Este é um dos meus pontos de partida.

Há uma distinção entre duas formas de democracia: a parlamentar e aquela baseada no diálogo direto. Na forma parlamentar, os eleitores votam em representantes e deixam para eles os julgamentos. Os eleitores devem acreditar que seu voto será bem utilizado. A forma alternativa é a democracia com diálogo, que requer negociação, debates... Neste caso, a dificuldade consiste em avaliar a representatividade das pessoas envolvidas nesse diálogo e o resultado do processo.

Tenho realizado pesquisa com pessoas deficientes. Na sociedade britânica, elas representam aproximadamente $10 \%$ da população, mas não estão sendo ouvidas, não tomam

\footnotetext{
* Palestra apresentada em maio de 2004, no Rio de Janeiro, promovida pelo Centro de Estudos/Museu da Vida/ COC/Fiocruz e pelo British Council/Rio de Janeiro.

** O projeto conta com parceria da University of Newcastle, da University of Durham e do International Centre for Life.
} 
parte em decisões importantes. O norte-americano Philip Kitcher, Ph.D em filosofia da ciência, diz que "ciência bem organizada deve ter pessoas que são atingidas pela ciência, tomando parte nos debates, incluindo os deficientes".

No Reino Unido, há o entendimento de que "os debates científicos precisam ser dominados por especialistas". As pessoas comuns temem não saber os detalhes técnicos sobre determinado assunto. Acontece que existem os especialistas técnicos, existem os especialistas éticos e os teólogos. E todos se acham no direito de dizer o que é certo e o que é errado. O problema é que os resultados da ciência são, freqüentemente, contraintuitivos ou desconhecidos e rejeitados pelos cidadãos comuns.

A razão pela qual o diálogo sobre os avanços da ciência e da tecnologia deve ser mais amplo é que todos nós somos afetados pela ciência e pela medicina. Somos consumidores de alimentos, tomamos remédios, recebemos diagnósticos, passamos por tratamentos médicos e participamos de pesquisas médicas. Como cidadãos, votamos em questões relacionadas à economia e à defesa. Deveríamos também votar em questões relacionadas à pesquisa e aos cuidados com a saúde.

Há cerca de vinte anos, no Reino Unido, foi divulgado o Relatório Bodmer, que concluía que a ciência havia perdido a confiança das pessoas. Nesse contexto, surgiu como solução o que foi chamado de Public Understanding of Science (Compreensão Pública da Ciência), que surgiu como uma forma de promover as "relações públicas da ciência". Essa nova modalidade de abordagem partiu do princípio de que, se as pessoas não gostavam de ciência, era porque elas não entendiam a ciência. Mas se os especialistas explicassem a ciência, o público gostaria mais. Ou seja, uma vez que a ignorância fosse removida, haveria aceitação.

A idéia de "Engajamento Público", no entanto, é mais igualitária. Neste tipo de participação, defende-se que "a ciência tem conhecimento, mas não em tudo". O público tem seu próprio conhecimento. Então, o necessário seria criar uma via de mão-dupla: o "conhecimento público da ciência" e o "conhecimento da ciência sobre o público".

No Reino Unido, temos tido alguns desastres, como o mal da vaca louca (BSE), que desgastaram a crença das pessoas na ciência. São frutos da ausência de diálogo, de não se ouvir o que as pessoas falam. Devemos ouvir mais os apelos dos cidadãos.

O que a democracia deliberativa faz para ouvir as diferentes vozes da sociedade? Uma forma de pesquisar a opinião pública consiste em pegar uma prancheta e fazer perguntas objetivas. Mas isso é muito superficial, não permite saber o que as pessoas entendem, o que elas pensam e por quê. Além disso, as pessoas nem sempre dão boas respostas.

Há, no entanto, outras formas de envolver o público na tomada de decisões relativas à ciência e à tecnologia. Existem maneiras de fazer que os cidadãos comuns tomem parte no debate em ciência e sejam ouvidos, conduzindo também a trajetória da tecnologia, decidindo em que direção devemos ir.

Um exemplo é o trabalho da Sociedade Alzheimer, que financia pesquisa médica sobre essa doença e sobre as possíveis técnicas de tratamento. Os membros da sociedade organizaram uma rede chamada Quality Researching Dementia, que reúne cerca de 150 pessoas, incluindo não-especialistas que cuidam de doentes de Alzheimer, parentes ou mesmo os próprios doentes. Essa rede recebe as propostas dos cientistas que buscam apoio financeiro junto à Sociedade Alzheimer para fazer pesquisa sobre a doença. Os cientistas têm que escrever um resumo que não-especialistas possam entender. Os membros da rede fazem perguntas sobre os projetos, traçam comentários, fazem sugestões... 
Eles estão ativamente envolvidos na decisão sobre quais pesquisas devem ser financiadas e como. Obviamente, não fazem isso sozinhos. A revisão por pares é vital. Mas o importante é que cidadãos comuns estão se reunindo e começando a se interessar pelo que acontece nessa área.

Outro exemplo é o National Institute for Clinical Excellence, uma instituição nova no Reino Unido que fornece serviço de saúde internacional. O Instituto está decidindo quais drogas devem ser subsidiadas pelo serviço médico estatal, quais tratamentos são apropriados e o que o serviço de saúde deve disponibilizar à sociedade. Muitas questões envolvem expertise, economia e acesso a tratamentos. Há especialistas técnicos para auxiliar nessas questões. Mas existem também questões de valores e julgamentos. Por exemplo, quem deve ser priorizado? Os jovens ou os idosos? Onde deve estar o equilíbrio nos cuidados com a saúde? Quando é esse o caso, o Instituto consulta o 'conselho cidadão', um grupo de trinta pessoas representativas da população, em sentido amplo: idosos, jovens, homens, mulheres, deficientes, não-deficientes... O grupo se reúne por três dias para debater a questão e formular um julgamento sobre ela. Esse tem sido um passo importante para o Instituto, que tem levado tal consulta muito a sério. Ele faz parte do Sistema Nacional de Saúde, e, para ter legitimidade, sente que deve envolver as pessoas em decisões.

O mesmo ocorre no 'júri de cidadãos', um mecanismo de engajamento público. Um grupo de facilitadores é usado para encontrar pessoas, ao acaso. Depois, o grupo avalia se elas são representativas do público em geral. Um júri de cidadãos tem o mesmo modelo e a mesma idéia de um julgamento criminal. Em um julgamento criminal, cidadãos comuns são escolhidos ao acaso para julgar se uma pessoa é culpada ou inocente. O juiz deve garantir que as leis sejam cumpridas durante o processo. As testemunhas fornecem evidências e o júri decide. Em um júri de cidadãos, acontece exatamente o mesmo, porém, o que está em julgamento são questões técnico-científicas. Antigamente, a decisão ficava a cargo de especialistas e do governo. Mas e se o governo estiver sofrendo pressão de lobbies? E se o especialista tiver opinião tendenciosa? Talvez o público não acredite nos resultados. Esta é uma alternativa que pode ser transparente, aberta e pública. Mas como convocar os membros do júri? Na Inglaterra, existe o que chamamos de registro eleitoral [como no Brasil], onde estão registrados todos os adultos que podem votar. Ele é usado para escolher pessoas ao acaso. Essas pessoas recebem um convite: "Você gostaria de participar? Você não é obrigado, mas gostaria?". São convocadas de 12 a 15 pessoas. O número exato não importa. O que importa é que elas sejam amplamente representativas da população. Há também as testemunhas, responsáveis por fornecer as evidências e os argumentos. Deve haver um equilíbrio entre as testemunhas de ambos os lados. $\mathrm{O}$ grupo diretor, por sua vez, é responsável por todo o processo e por fazê-lo funcionar. Existe ainda o grupo consultor, que deve se preocupar com a transparência e o equilíbrio, responsável também por recrutar as testemunhas. A razão pela qual esse mecanismo vem dando certo é porque políticos e formuladores de políticas o têm levado a sério. Eles escutam o júri. E todos concordam que esse é o caminho certo.

Um júri de cidadãos aconteceu em Andhra-Pradesh, na Índia. Mesmo pessoas analfabetas, sem nenhuma educação formal, participaram. O futuro, os alimentos e a agricultura foram alguns dos temas principais escolhidos. As pessoas discutiram as possibilidades de desenvolver na região a agricultura de subsistência.

Um júri de cidadãos pode ter qualquer assunto como tema. $\mathrm{O}$ tema pode partir também de perguntas do tipo: “O que interessa a nós? Sobre o que gostaríamos de ter um 
júri de cidadãos?". Em uma ocasião, fizemos em Newcastle, Reino Unido, um júri de cidadãos com um grupo de idosos. Deixamos que eles escolhessem o tema. Eles decidiram que gostariam de saber como prevenir quedas e acidentes com pessoas idosas. Quando idosos caem, eles quebram ossos, vão para hospitais e eventualmente morrem. Esse é um grande problema que os preocupa muito. Portanto, queriam saber: "Como acontecem essas quedas? Como evitá-las?". Esse foi o tema do júri. Havia testemunhas, havia especialistas e, no final, o júri formulou um julgamento. Alguns membros do júri ficaram surpresos e comentaram: "Quando você imagina um júri, você pensa em uma corte formal, uma sala de audiência...". Mas o ambiente foi descontraído. Havia essa atmosfera em que é possível formular questões abertamente para profissionais, conversar com eles... A questão é: "Podemos ter certeza de que irá fazer alguma diferença?". Os júris sempre podem ajudar porque é sempre bom dar mais poder às pessoas. Mas podemos saber realmente se produzirá mudança social? O grande problema, entretanto, é: “Vai fazer realmente alguma mudança social?".

Na medida em que o júri progride, as pessoas se entusiasmam. Todos nós gostamos quando os júris são positivos para as pessoas, e outros júris poderão também ser assim. Há uma estrutura, um diálogo e um progresso. Como em vários outros experimentos de participação popular: você cria uma estrutura em que pessoas comuns são valorizadas, na qual elas podem aprender sobre os diferentes argumentos apresentados ao longo do processo.

Há condições necessárias para se ter um equilíbrio. É preciso ter em mente também que algumas questões fogem à lógica e às evidências, pois envolvem sentimento e emoção. É preciso respeitar isso. Você não será necessariamente guiado pelos sentimentos e emoções, mas é preciso abrir espaço para que eles sejam reconhecidos. Em questões de bioética e genética, as pessoas sabem certas coisas. Não precisam ter diploma superior ou educação secundária, precisam apenas ter um conhecimento básico. Por exemplo, no Reino Unido, as pessoas que se opunham aos alimentos geneticamente modificados ficaram muito chateadas ao saber que existem genes em tomates. $O$ fato de haver genes em todas as coisas vivas foi um bom ponto de partida. Genes não são alienígenas, são partes dos blocos básicos que formam a vida. Aí está um pedaço básico de educação. Não os detalhes, mas os princípios.

Podem restar alguns problemas teóricos, particularmente em bioética. Um deles é o fator "Argh!". Atualmente, estão sendo discutidas na Grã-Bretanha as células-tronco embrionárias, a tecnologia para que elas possam se desenvolver e gerar tecidos. Existem diversos pontos de vista sobre isso. Muitos dizem: "Argh! Eu não gosto disso!". Seria uma reação emocional? Ou fruto de falta de familiaridade com o assunto? Devemos levar isso em conta? Quando os transplantes de órgãos foram iniciados, em 1950, as pessoas falaram "Argh! O coração de outra pessoa no meu corpo?"; "Aproveitar o coração de um cadáver?". Na história da medicina, vemos, de tempos em tempos, o fator "Argh!". É normal, mas não deve ser seguido. $\mathrm{O}$ fato de algo ser verdadeiro, um fato social, não significa que deva ser um fato.

Na Grã-Bretanha, seria possível obter resultados em uma pesquisa de opinião que defendessem a adoção do enforcamento, novamente. Isso não significa que se deva efetivamente utilizar essa punição, como no passado. Essa é uma grande questão na democracia, em todas as formas de democracia. Como equilibrar aquilo que é e aquilo que deve ser? Essas formas de democracia deliberativa não resolvem, necessariamente, 
esse problema. Mas elas trazem à luz diferentes argumentos em que os especialistas geralmente não pensam. Eles tratam de valores. Talvez seja mais sábia uma decisão baseada em valores.

Quando o assunto é pesquisa com células-tronco embrionárias, há diferenças incontornáveis. Se você é católico, você acha que a vida se inicia na concepção, e nenhuma discussão vai mudar isso. É uma questão de fé. Há outras questões, mais "frias", como: os participantes são representativos da população em geral? Se eles não são representativos, quando o júri de cidadãos for divulgado, as pessoas vão dizer: "Tudo bem, mas quem são essas pessoas?"; "Eu não as escolhi"; "Elas não representam meus interesses e preocupações"; "Por que eu deveria acreditar nelas?". Assim como acontece em relação aos políticos. No início, eles vêm do povo, mas terminam sendo distintos do povo.

Outra questão é que todas essas formas de consultas têm custos. Elas tomam tempo e dinheiro quando praticadas com seriedade.

Há, finalmente, o que nomearam de "rituais de precisão": o júri de cidadãos baseia-se no júri criminal. E numa corte criminal existem regras. As testemunhas não se misturam com o júri. O júri fica isolado de pessoas que possam influenciá-lo. Certifica-se sempre que o júri está seguindo as regras. É necessário manter a independência. Algumas vezes os júris são criados por governos ou empresas. Isso nos preocupa, porque talvez tudo tenha sido "arranjado", ou as pessoas, ou testemunhas, tenham sido escolhidas para forçar o resultado em uma certa direção. Esses casos tornam-se o que se pode chamar de "tecnologia de legitimação", uma outra maneira de apoiar a elite dominante. Há riscos, que não necessariamente comprometem os júris dos cidadãos, mas aos quais devemos estar sempre atentos.

Tradução do inglês para o português: Bruno Buys.

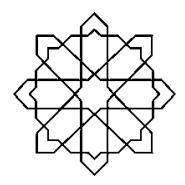




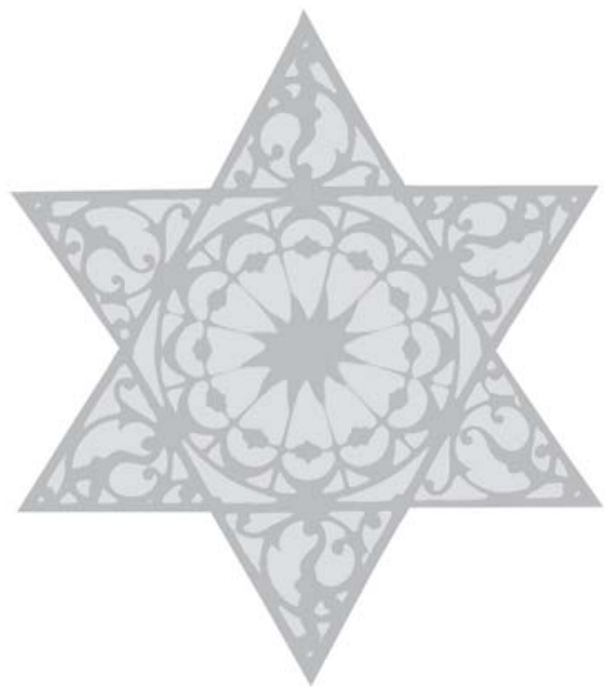

